\title{
Pengaruh Kegiatan Kolase Ampas Kelapa Berwarna Terhadap Kreativitas Anak Usia 5-6 Tahun Di TK Negeri Pembina I Binjai
}

Received : 10 Oktober 2019

Revised : 20 Oktober 2019

Accepted : 2 November 2019

\author{
Syafriana Insani ${ }^{1}$, Damaiwaty Ray $^{2}$ \\ Fakultas Ilmu Pendidikan \\ Universitas Negeri Medan \\ Jln. Willem Iskandar Psr V Medan Estate \\ E-mail : syafrianainsani@gmail.com
}

\begin{abstract}
Abstrak. Permasalahan dalam penelitian ini adalah anak yang sering bergantung pada apa yang di contohkan oleh guru, sehingga anak cenderung pasif. Penelitian ini bertujuan agar anak di TK Negeri Pembina I Kota Binjai lebih kreatif.

Jenis penelitan ini adalah eksperimen, populasi dalam penelitian ini adalah seluruh anak di TK Negeri Pembina I kota Binjai, yang berjumlah 2 kelas yaitu B1 dan B2 yang masingmasing kelas berjumlah 40 dan 33 anak. Sampel dalam penelitian ini yaitu kelas B2 sebagai kelas eksperimen dan kelas B1 sebagai kelas kontrol dengan teknik random sampling. Sedangkan teknik pengumpulan data yang digunakan dalam penelitian adalah observasi terstruktur dan analisis data yang dilakukan dalam penelitian ini yaitu analisis deskriptif dengan uji t dengan taraf nyata $\alpha=0,05$.

Dalam penelitian ini variabel yang dikembangkan ialah variabel terikat berupa perkembangan kreativitas indikator yang diamati yaitu menghasilkan ide baru dan memecahkan masalah. Sedangkan variabel bebas dalam penelitian ini ialah kegiatan kolase dengan ampas berwarna indikator yang diamati yaitu karya seni dan teknik menempel.Berdasarkan analisis data diperoleh rata-rata nilai kelas eksperimen 10,775 dengan nilai tertinggi 12 dan nilai terendah 9, sehingga perkembangan kreativitas anak pada kelas eksperimen tergolong dalam kategori tinggi. Sedangkan nilai rata-rata pada kelas kontrol 5,818 dengan nilai tertinggi 7 dan nilai terendah 4 sehingga perkembangan kreativitas anak pada kelas kontrol tergolong dalam kategori cukup. Dari hasil Uji normalitas kelas eksperimen diperoleh $\mathrm{L}_{\text {hitung }}<\mathrm{L}_{\text {tebel }}$ yaitu $0,183<0,886$, dan kelas kontrol $\mathrm{L}_{\text {hitung }}<\mathrm{L}_{\text {tebel }}$ yaitu $0,1364<0,886$. Dari pengujian homogenitas diperoleh $\mathrm{F}_{\text {hitung }}=1,045$ dan $\mathrm{F}_{\text {tabel }}=1,805$. Kemudian dari uji hipotesis $\mathrm{t}_{\text {hitung }}>\mathrm{t}_{\text {tabel }}$ yaitu $19,592>1,673$. Maka hipotesis $\mathrm{H}_{\mathrm{o}}$ ditolah dan $\mathrm{H}_{\mathrm{a}}$ diterima, sehingga dapat dinyatakan bahwa kegiatan kolase dengan ampas kelapa berpengaruh terhadap kreativitas anak usia 5-6 tahun di TK Negeri Pembina I Kota Binjai.
\end{abstract}

Kata Kunci: kolase, ampas kelapa berwarna, kreativitas anak

\section{PENDAHULUAN}

Utami Munandar (dalam Ahmad Susanto, 2010: 111) mengemukakan bahwa kreativitas sangat penting untuk dikembangkan pada anak usia dini, dengan berkreasi anak dapat mewujudkan dirinya, sebagai kemampuan untuk melihat bermacam-macam kemungkinan penyelesaian terhadap suatu masalah dalam meningkatkan kualitas hidupnya. Oleh karena itu, kreativitas sangatlah penting dikembangkan pada anak sejak dini untuk persiapan kehidupan dimasa yang akan datang. Anak memiliki potensi kreativitas alami, maka senantiasa mampu menumbuhkan aktivitas yang sarat dengan ide-ide kreatif. Secara natural anak memiliki kemampuan untuk mempelajari sesuatu menurut carannya sendiri. Untuk mempertahankan daya kreatif dan keterampilan pada anak, guru harus lebih memperhatikan sifat natural anak-anak yang sangat menunjang tumbuhnya kreativitas, 
yang harus senantiasa dipupuk dan dikembangkan oleh guru sehingga sifat kreatif mereka tidak hilang. Guru berperan penting dalam mengembangkan kreativitas anak, harus bisa memlilih dan memanfaatkan setiap kesempatan belajar untuk mengembangkan kreativitas anak. Guru dapat mengajak anak untuk mengembangkan kreativitasnya dalam kesempatan apa saja baik di dalam ruangan maupun di luar ruangan dengan kegiatan-kegiatan yang menarik bagi anak.

Namun yang terjadi dilapangan belum sesuai dengan harapan. Hal ini dapat terlihat pada saat melakukan suatu kegiatan, anak hanya mampu meniru apa yang dicontohkan oleh guru, dan anak cenderung lebih pasif. Dalam pembelajaran yang dilakukan oleh guru, ada kendala yang dialami oleh guru, yaitu keterbatasan pada waktu sehingga guru tidak memberi kebebasan kepada anak didalam melakukan suatu kegiatan. Dengan demikian tidak terlihat kreativitas yang seharusnya sudah dimiliki oleh anak kelas B1 tersebut. Dan dengan begitu, sebuah kegiatan pembelajaran yang menarik untuk mengembangkan kreativitas anak yaitu melalui kegiatan kolase dengan ampas kelapa berwarna, karena dengan kegiatan tersebut anak dapat berkreasi sesuai dengan kreativitas anak masingmasing dan merupakan kegiatan menarik bagi anak.

Novikasari menjelaskan tentang pengaruh kegiatan kolase terhadap kreativitas (http://jurnal.untad.ac.id/jurnal/index.php/Bungamputih/article/view/7266/5853) yaitu, Kolase merupakan kegiatan yang dapat mengembangkan kemampuan kreativitas anak. Kolase adalah kegiatan anak yang berupa kegiatan menempel, dan merekatkan objek yang akan dibuat menjadi hasil karya kolase. Anak dapat menempel atau merekatkan bahanbahan yang tersedia sesuai dengan kreativitas masing-masing.Kegiatan kolase membantu kemampuan berbahasa anak, anak terlatih untuk menjelaskan atau bercerita tentang hasil karyanya kepada guru, selain itu kegiatan kolase yang merupakan kegiatan berseni rupa yang diwujudkan dengan teknik menempel dan menyusun bahan yang di sediakan dapat membantu anak dalam mengembangkan aspek motorik halus, dengan menempel dan merekatkan bahan motorik halus anak akan terlatih dan dapat berkembang dengan optimal. Pada saat melakukan kegiatan kolase sama halnya anak sedang bermain, sehingga dalam proses pembelajarannya berlangsung dengan menyenangkan dan dapat meningkatkan kreativitas anak.Kegiatan kolase bagi anak TK adalah kemampuan berolah seni rupa yang diwujudkan dengan keterampilan menyusun dan merekatkan bagian-bagian bahan alam, bahan buatan dan bahan bekas pada kertas gambar/bidang dasaran yang digunakan, sampai dihasilkan tatanan yang unik dan menarik.

\section{METODOLOGI PENELITIAN}

Metode penelitian yang digunakan dalam penelitian ini adalah metode penelitian eksperimen.Desain dalam penelitian ini adalah True EksperimentalDesign, dengan bentuk Postest-Only Control Design dalam model ini terdapat kelompok eksperimen dan kelompok Kontrol yang dipilih secara random. Sugiyono (2010:117) mengatakan populasi adalah wilayah generalisasi yang terdiri atas : objek/subjek yang mempunyai kualitas dan karakteristik tertentu yang ditetapkan peneliti untuk dipelajari dan kemudian ditarik kesimpulannya. Dari definisi diatas, maka populasi dalam penelitian ini adalah seluruh anak di TK Negeri Pembina I Binjai T.A 2017/2018. Adapun anak kelompok B terdiri dari 2kelas dengan jumlah 73 anak, yaitu kelas B1 berjumlah 40 orang, dan pada B2 berjumlah 33 orang.

Dalam penelitian ini teknik pengumpulan data yang digunakan adalah observasi. Metode observasi dilakukan dengan cara mengamati dan mencatat semua aktivitas anak pada 
proses kegiatan kolase di kelas. Observasi dilakukan pada anakkelompok Buntuk memperoleh data anak yang berkaitan dengan aspek-aspek kreativitas anak.Penyusunan data dilakukan dengan memuat namaanak.Tugas observer memberi tanda checklist $(\checkmark)$ pada skor yang di dapat melalui pedoman observasi yang dibuat. Dari observasi yang dilakukan maka diperoleh data tentang pengaruh darikegiatan kolase ampas kelapa terhadap kreativitas anak usia 5-6 tahun.

Tabel 1. Kisi - Kisi Perkembangan Kreativitas Anak

\begin{tabular}{|c|c|c|}
\hline Variabel & Indikator & Deskriptor \\
\hline \multirow[t]{4}{*}{ Kreativitas } & Menempel Kolase & $\begin{array}{l}\text { a. Menempel pada satu pola } \\
\text { b. Menempel pada tiga pola } \\
\text { c. Menempel pada seluruh gambar }\end{array}$ \\
\hline & $\begin{array}{l}\text { Menghasilkan ide } \\
\text { baru }\end{array}$ & $\begin{array}{l}\text { a. Menempel dengan mencampurkan dua } \\
\text { warna } \\
\text { b. Berani mengungkapkan pendapatnya } \\
\text { c. Menempel pada pola secara bebas, } \\
\text { (berurutan atau secara acak) }\end{array}$ \\
\hline & $\begin{array}{l}\text { Mengkombinasi } \\
\text { warna }\end{array}$ & $\begin{array}{l}\text { a. Menggunakan satu warna } \\
\text { b. Menggunakan tiga warna } \\
\text { c. Menggunakan 5-7 warna }\end{array}$ \\
\hline & $\begin{array}{l}\text { Memecahkan } \\
\text { masalah }\end{array}$ & $\begin{array}{l}\text { a. Mampu menempel sesuai pola (tidak } \\
\text { keluar garis } \\
\text { b. Mampu mengerjakan tugas sampai } \\
\text { selesai } \\
\text { c. Berani bertanya dan menjawab } \\
\text { pertanyaan }\end{array}$ \\
\hline
\end{tabular}

\section{HASIL DAN DISKUSI}

Telah diterangkan sebelumnya pada bab III bahwa dalam penelitian ini dikumpulkan dengan teknik observasi. Lembar observasi telah disusun sehingga dapat digunakan untuk melihat data perkembangan kreativitas anak.

Dari observasi, dapat dilihat bahwa dengan kegiatan membatik memberikan perbedaan pada perkembangan kreativitas anak di kelas kontrol dan kelas eksperimen. Perbedaan tersebut dapat dilihat dalam tabel dibawah ini 
Tabel 4.5 Perbedaan Hasil Data Kelas Eksperimen dan Kelas Kontrol

\begin{tabular}{lcclcc}
\hline & \multicolumn{3}{c}{ Kelas Ekperimen } & \multicolumn{3}{c}{ Kelas Kontrol } \\
\hline No & $\begin{array}{c}\text { Nilai Observasi } \\
\text { Akhir }\end{array}$ & Frekuensi & No & $\begin{array}{c}\text { Nilai Observasi } \\
\text { Akhir }\end{array}$ & Frekuensi \\
\hline 1. & 9 & 6 & 1. & 4 & 5 \\
\hline 2. & 10 & 11 & 2. & 5 & 7 \\
\hline 3. & 11 & 9 & 3. & 6 & 10 \\
\hline 4. & 12 & 14 & 4. & 7 & 11 \\
\hline Jumlah & $\mathbf{4 0}$ & Jumlah & $\mathbf{3 3}$ \\
\hline Rata-rata $=\mathbf{1 0 , 7 7 5}$ & \multicolumn{5}{l}{ Rata-rata $=\mathbf{5 , 8 1 8}$} \\
\hline Simpangan Baku = 1,097 & \multicolumn{5}{l}{ Simpangan Baku = 1,073 } \\
\hline
\end{tabular}

Dari tabel diatas dapat dilihat bahwa ada perbedaan antara kelas eksperimen dan kelas kontrol. Pada kelas Eksperimen jumlah frekuensinya adalah 40, dengan nilai rata-rata 10,775 dan simpangan baku 1,097. Dikelas kontrol jumlah frekuensi 33 dengan nilai ratarata 5,818 dan simpangan baku 1,073. Dari hasil diatas selisih nilai rata-rata anak sebanyak 4,957.Maka dari itu terlihat bahwa kegiatan kolase dengan ampas kelapa berwarna dikelas eksperimen lebih besar perkembangan kreativitasnya dibanding kelas kontrol yang membatik dengan teknik celup.

\section{PEMBAHASAN}

Pada proses memperoleh hasil analisis data, sebelum memberikan perlakuan yang berbeda pada kedua kelas yaitu kelas eksperimen dan kelas kontrol disimpulkan bahwa perkembangan kreativitas anak adalah sama, yakni berdasarkan tingkat usia kelas eksperimen dan kelas kontrol yaitu masing-masing berusia 5-6 tahun.

Kegiatan kolase ini ialah sebuah kegiatan membuat gambar 2D menjadi gambar 3D dengan cara menempelkan ampas kelapa berwarna pada pola. Dengan kegiatan kolase banyak manfaat yang akan didapat anak, yaitu dapat mengembangkan kreativitasnya, melatih konsentrasi anak, sabar dalam berlatih dan terus-menerus melakukan secara berulangulang.

Setelah dilakukan perlakuan yang berbeda diperoleh skor kreativitas anak kelas eksperimen 10,775, sedangkan di kelas kontrol 5,818. Dari hasil observasi kedua kelas tersebut diperoleh selisih skor 4,957. Dari data yang diperoleh terdapat perbedaan yang signifikan antara perkembangan kreativitas anak di kelas eksperimen dan dikelas kontrol. Hal ini disebabkan karena kegiatan kolase dengan ampas kelapa berwarna menarik untuk anak.

Berdasarkan data diatas dapat diketahui bahwa perkembangan kreativitas anak pada kelas eksperimen yang diberikan perlakuan dengan kegiatan kolase dengan ampas kelapa berwarna mengalami peningkatan yang lebih baik dari kelas kontrol yang melakukan kegiatan menempel gambar pola.

Maka berdasarkan penelitian yang telah dilakukan di TK Negeri Pembina I Kota Binjai dapat disimpulkan bahwa kegiatan kolasesangat berpengaruh terhadap perkembangan kreativitas anak 


\section{SIMPULAN}

Berdasarkan hasil penelitian dan pengolahan data pada sub bab sebelumnya dapat di ambil kesimpulan, yaitu :

1. Perkembangan kreativitas anak dikelas eksperimen yang dikembangkan melalui kegiatan kolase dengan ampas kelapa berwarna lebih baik dibandingkan perkembangan kreativitas anak dikelas kontrol yaitu menempel gambar pola.

2. Hasil observasi dilakukan melalui 3 tahap pengujian yaitu uji normalitas, uji homogenitas, dan uji hipotesis. Dalam uji normalitas dikelas eksperimen diperoleh $\mathrm{L}_{\text {hitung }}<\mathrm{L}_{\text {tabel }}$ yaitu $0,183<0,886$ dan dikelas kontrol $\mathrm{L}_{\text {hitung }}<\mathrm{L}_{\text {tabel }}$ yaitu $0,1364<0,886$. Dari pengujian homogenitas diperoleh $\mathrm{F}_{\text {hitung }}=1,045$ dan $\mathrm{F}_{\text {tabel }}=1,805$. Kemudian dari uji hipotesis $t_{\text {hitung }}>t_{\text {tabel }}$ yaitu 19,592 $>1,673$. Dengan demikian hipotesis $\mathrm{H}_{0}$ ditolak dan Ha diterima, sehingga dapat dinyatakan bahwa "Ada pengaruh dari kegiatan kolase dengan ampas kelapa berwarna terhadap perkembangan kreativitas anak usia 5-6 tahun di TK Negeri Pembina I Kota Binjai”.

Berdasarkan kesimpulan diatas, maka peneliti mengajukan beberapa saran yaitu :

1. Bagi guru diharapkan mampu dan terampil membuat variasi kegiatan kolase agar kreativitas anak semakin berkembang.

2. Bagi kepala sekolah dapat memberikan kemudahan kepada guru untuk mengikuti pelatihan tentang perkembangan kreativitas anak.

3. Bagi peneliti selanjutnya diharapkan dapat meneliti tentang kolase lainnya.

\section{DAFTAR RUJUKAN}

Asmawati, Luluk. 2014. Perencanaan Pembelajaran PAUD. Bandung: Remaja Rosda Karya

Einon, Dorothy. 2006. Permainan Kreatif untuk Anak-Anak. Batam: Kharisma Publishing Group

Fadlillah, Muhammad. 2014. Edutainment Pendidikan Anak Usia Dini. Yogyakarta: Kencana.

Kurniawan, Heru. 2016. Sekolah Kreatif sekolah yang menyenangkan untuk anak. Yogyakarta: Ar-Ruzz Media

Masnipal. 2013. Siap Menjadi Guru dan Pengelola PAUD Profesional. Jakarta: Kompas Gramedia

Mutiah, Diana. 2012. Psikologi Bermain Anak Usia Dini. Jakarta: Kencana

Puspita Devi, Fratnya. 2014. E-jurnal Peningkatan Kreativitas Melalui Kegiatan Kolasehttp://www.e-jurnal.com/2015/06/peningkatan-kreativitas-melalui.html (diakses 20 Maret 2017)

Sofa. 2011. Mengenal Kreativitas Anak Sejak Dini https://massofa.wordpress.com/2011/09/23/mengenal-kreativitas-anak-sejakdini/ (diakses 20 Maret 2017)

Solichah, Silvana dan N. Ayusari. 2017. Keterampilan Kolase. Yogyakarta: Indopublika. Sudjana. 2005. Metode Statistika. Bandung: Tarsito

Sugiyono. 2010. Metode Penelitian Pendidikan. Bandung: Alfabeta

Susanto, Ahmad. 2011. Perkembangan Anak Usia Dini: Pengantar Dalam Berbagai Aspeknya. Jakarta: Kencana 